九州大学学術情報リポジトリ

Kyushu University Institutional Repository

\title{
Genetic Diversity of Myanmar Rice Cultivars Detected by DNA markers
}

Saw, Ohm Mar

Graduate School of Bioresource and Bioenvironmental Sciences, Kyushu University

Doi, Kazuyuki

Faculty of Agriculture, Kyushu University

Khin, Aye

Seed Bank, Department of Agricultural Research, Yezin

Irie, Kenji

Tokyo University of Agriculture

他

https://doi.org/10.5109/9227

出版情報：九州大学大学院農学研究院紀要. 51 (2)，pp. 181-187，2006-10-27. Faculty of Agriculture, Kyushu University

バージョン :

権利関係 : 


\title{
Genetic Diversity of Myanmar Rice Cultivars Detected by DNA markers
}

\author{
OHM MAR SAW ${ }^{1}$, Kazuyuki DOI, KHIN AYE ${ }^{2}$ Kenji IRIE ${ }^{3}$ \\ and Atsushi YOSHIMURA*
}

\author{
Laboratory of Plant Breeding, Division of Genetics and Plant Breeding, Department of Applied Genetics \\ and Pest Management, Faculty of Agriculture, Kyushu University, \\ Fukuoka 812-8581, Japan \\ (Received April 15, 2006 and accepted July 24, 2006)
}

\begin{abstract}
Genetic diversity of Myanmar cultivated rice accessions was evaluated by DNA markers. The materials included 110 accessions from six different regions of Myanmar and 17 accessions from other countries. Twelve RFLP markers, 6 STS markers and 28 CAPS markers were used. An UPGMA dendrogram was constructed to infer the phylogenetic relationships of the materials. The stability of the nodes in the tree was tested by the bootstrap analysis. All accessions except two could be distinguished from each other by at least one DNA marker. The dendrogram revealed 2 well-distinguished groups, namely, Group I and II. Group I corresponded Japonica. It was further divided into two subgroups Ia and Ib. The subgroup Ia contained Japanese Japonica accessions and all the accessions in the subgroup Ib were Myanmar accessions clearly differentiated from the subgroup Ia. Indica accessions were contained in Group II. It comprised small clusters. Bootstrap analysis was performed to determine the confidence levels of the forks in the dendrogram. In the resulting consensus tree, only 6 forks had bootstrap values above 80\%. The grouping of the UPGMA tree and the majority-rule consensus tree were comparable in the subgroups Ia, Ib and IIe. However, the Indica subgroups, Ia, Ib, Ic and IId were not significantly differentiated.
\end{abstract}

\section{INTRODUCTION}

Rice, Oryza sativa L., is one of the agronomically and nutritionally important cereal crops and is the principal staple food for more than half of the world population. A main part of the genetic improvement of a crop resides in the creation of new combinations of genes from the available germplasm. In this perspective, the first concern of breeders is to know the genetic structure of the existing germplasm.

A large number of crop species, including rice, originated from the Hindustan center, which contained India, Assam, and Myanmar (Vavilov et al., 1926). The origin sites of cultivated rice are located in a wide region extending from the Ganges plains, northern Myanmar, northern Thailand, Laos, northern Vietnam and southwest and southern China. (Matsuo, 1997; Chang, 1976). Nakagahra (1978) estimated the center of the diversity of Asian rice might be located at mountainous regions on the northern side of Southeast Asia, such as Myanmar, Thailand, and Yunnan in China.

As an origin of rice cultivation, Myanmar is one of the countries which have been found high in genetic diversity of rice and a part of the crop diversity area, and it also have heterogeneous geographical and ecological conditions such as hills and mountains. Geographically, Myanmar has six distinct regions: central dry zone,

\footnotetext{
1 Laboratory of Plant Breeding, Division of Genetics and Plant Breeding, Department of Applied Genetics and Pest Management, Graduate School of Bioresource and Bioenvironmental Sciences, Kyushu University

2 Seed Bank, Department of Agricultural Research, Yezin, Myanmar

${ }^{3}$ Faculty of International Agriculture and Food Studies, Tokyo University of Agriculture, Tokyo 156-8502, Japan

* Corresponding author (Email: ayoshi@agr.kyushu-u.ac.jp)
}

coastal strip region, delta region of Ayerwady and Sittaung rivers, eastern mountain region, northern mountain region, and western mountain region. As a staple food and crop with potential for export, rice is grown extensively in all of the six regions under all agro-ecological conditions.

There are 5770 accessions of rice germplasm collected and conserved in Myanmar Seed Bank Project in 2000 (Oka, 2000). The accurate identification of plant material in a gene bank is essential for effective germplasm characterization because breeders have no means to select appropriate materials for breeding programs without such information. The structure of genetic diversity is also important when considering the development of 'core collections' (Jackson et al., 1998). Further, without determining diversity reliably it would not be possible to identify molecular marker/quantitative trait association which have been shown to be useful in the process of germplasm evaluation (Virk et al., 1996).

The genetic variation of Asian cultivated rice has been studied by many researchers to classify landrace groups, to investigate phylogenetic differentiation, and to provide basic information for breeding. Oka (1953a and 1953b) systematically surveyed variations in several physiological, biochemical, and morphological characters and performed genetic analyses of hybrid sterility. He classified rice varieties into continental and insular types, subdividing the latter into tropical insular and temperate insular. The three groups of rice are generally recognized as Indica, Javanica, and Japonica. Variation of isozyme loci was intensively surveyed to make precise classification (Glaszmann, 1987; Nakagahra, 1978).

Although these classical methods were central, they are restricted in their resolving power mainly because of the small number of variables available. Nowadays, 


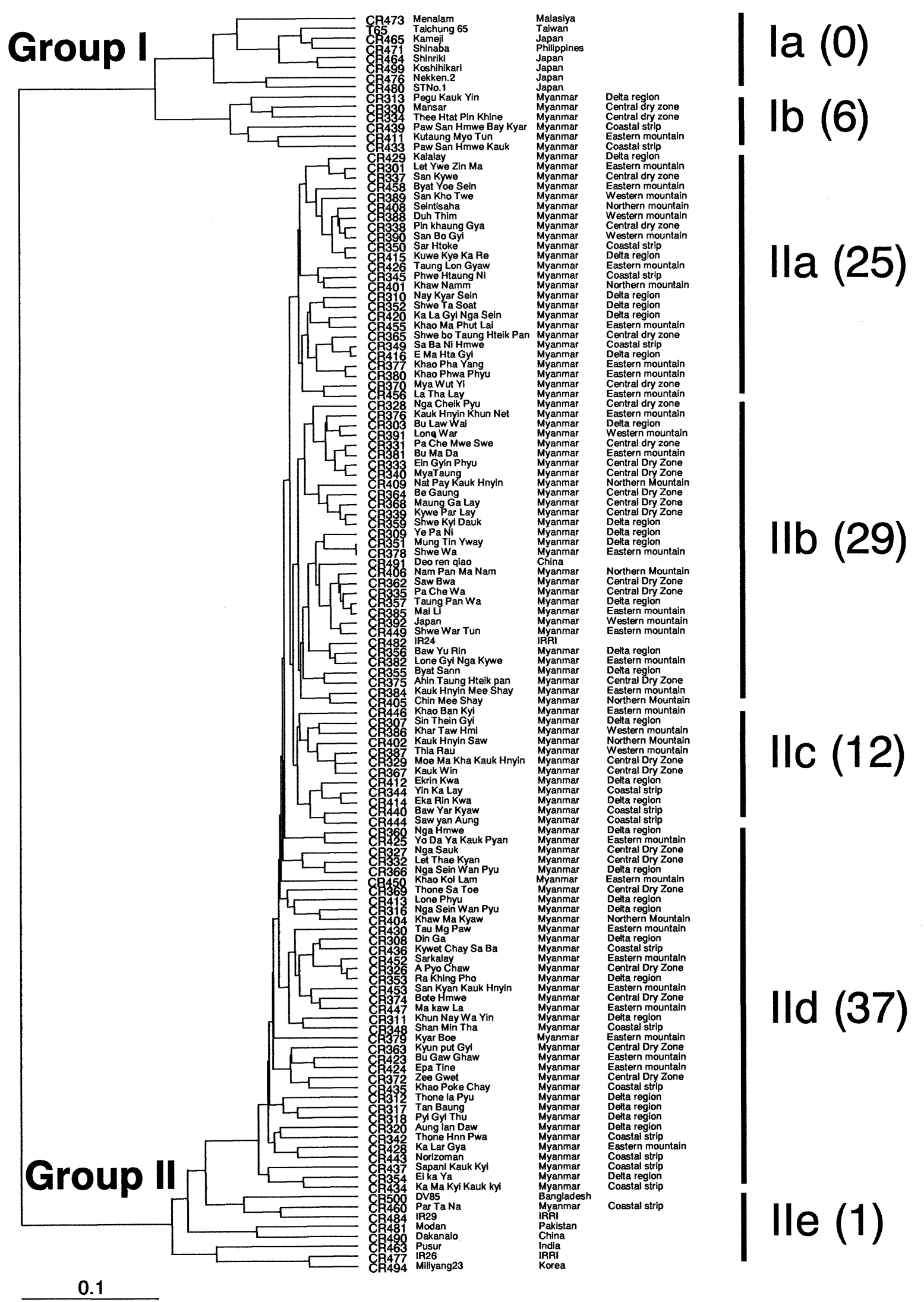

Fig. 1. Dendrogram generated by UPGMA method. Accessions from Myanmar are designated as CR301 to CR460. Numbers of Myanmar accessions contained in each group are shown in parentheses. 
there are several different DNA based methods for the identification of cultivars. Restriction fragment length polymorphism (RFLP) and polymerase chain reaction (PCR) have been widely used. RFLP are differences in the lengths of DNA fragments following digestion with restriction endonucleases. These polymorphisms are generally detected using single or low copy number nuclear DNA sequences as hybridization probes on Southern blots of restriction-digested genomic DNA. The development of RFLP marker has provided powerful tools in assessing the genetic differentiation and detecting the phylogenetic relationship between cultivated rice and wild rice (Wang and Tanksley, 1989; Zhang et al., 1992; Wang et al., 1992; Nakano et al., 1992; Doi et al., 2000; Sun et al., 2001). This approach, however, requires appreciable amounts of relatively pure DNA, is time consuming, costly, and is technically demanding.

On the other hand, PCR based markers such as random amplified polymorphic DNA (RAPD, Williams et al., 1990) and amplified fragment length polymorphism (AFLP, Vos et al., 1995) have the merit of revealing diversity without prior knowledge of genome sequence information but have the drawbacks of generating mainly dominant and anonymous markers (Skroch and Nienhuis, 1995; Shim and Jørgensen, 2000). Simple sequence repeat (SSR) markers have also been extensively used to generate multi-allelic and very variable markers (Ghebru et al., 2002; Enoki et al., 2002). Cleaved amplified polymorphic sequence (CAPS) methodology generates another type of molecular markers combining both PCR and RFLP techniques (Konieczny and Ausubel, 1993). This requires minute amounts of genomic DNA and simple electrophoresis systems to reveal polymorphism. CAPS markers have been successfully applied to a number of crop and forest species for which extensive nucleotide information is available (Chen et al., 1994; Ghreyazie et al., 1995; Tsumura et al., 1997; Perry et al., 1999).

The main objective of this research is to identify the genetic variation of Myanmar rice cultivars by using DNA markers and to get the information that allow to select appropriate materials within Myanmar rice cultivars for further breeding program.

\section{MATERIALS AND METHODS}

\section{Plant materials}

The numbers of the accessions and names of collection regions were shown in Table 1 . The materials included 110 accessions from 6 different regions of Myanmar and 17 accessions previously analyzed (Doi et $a l$. 2000). The 17 accessions including typical Japonica varieties and Inidica varieties were used as controls (Fig. 1).

\section{DNA extraction}

Frozen leaves of a single plant in each accession were collected and ground in liquid nitrogen. DNA was extracted from the ground tissues by the CTAB (Cetyltrimethyl ammonium bromide) method (Murray and Thompson, 1980).

\section{Detection of RFLP}

Probes used in this study were selected from clones located on the RFLP map constructed by Saito et al. (1991). RFLPs were detected from the combination of total DNA digested with Dra I, Hind III, or Eco RV and 12 probes (Table 2). DNA samples were digested with restriction endonuclease, and were electrophoresed on 0.8\% agrose gels using TAE (40 mM Tris-HCl pH 8.0, $40 \mathrm{mM}$ acetic acid, $1 \mathrm{mM}$ EDTA) as the running buffer. The gels were blotted onto a positively charged nylon membranes by capillary transfer in $0.4 \mathrm{~N} \mathrm{NaOH}$ for $12 \mathrm{~h}$. The membranes were washed in $2 \times \mathrm{SSC}$, dried, and baked at $120^{\circ} \mathrm{C}$ for $20 \mathrm{~min}$. Hybridization signals were detected according to the protocol of the ECL direct nucleic acid labeling and detection system (Amersham Biosciences, Tokyo, Japan) on X-ray films (FUJIFILM, Tokyo, Japan) for 1-3h.

\section{Genotyping of PCR marker loci}

Thirty-four PCR-based polymorphic markers including 6 sequence tagged site (STS) and 28CAPS markers covering 12 chromosomes of rice (Rice Genome Research Program) were used. The names of the markers and their located chromosomes are shown in Table 3. PCR amplification was performed on the GeneAmp PCR System 9700 (Applied Biosystems, Foster City, CA, USA) using the following amplification condition: 30 cycles of $94{ }^{\circ} \mathrm{C}(30 \mathrm{sec}), 60^{\circ} \mathrm{C}(1 \mathrm{~min})$, and $72{ }^{\circ} \mathrm{C}$ (1 min). The amplified products were digested with restriction enzymes as necessity. The DNA fragments

Table 1. Number of accessions in 6 regions of Myanmar and other countries

\begin{tabular}{lc}
\hline Region & Number of accessions \\
\hline Central dry zone & 25 \\
Coastal strip region & 18 \\
Delta region & 26 \\
Eastern mountain region & 27 \\
Northern mountain region & 7 \\
Western mountain region & 7 \\
Other countries & 17 \\
\hline Total & 127 \\
\hline
\end{tabular}

Table 2. RFLP markers used in this study

\begin{tabular}{rrlc}
\hline Probe (Npb) & Chromosome & Enzyme & $\begin{array}{l}\text { Number of } \\
\text { detected alleles }\end{array}$ \\
\hline 67 & 2 & Dra I & 3 \\
132 & 2 & Eco RV & 3 \\
15 & 3 & Eco RV & 2 \\
129 & 3 & Hind III & 2 \\
49 & 4 & Hind III & 2 \\
81 & 5 & Eco RV & 2 \\
27 & 6 & Eco RV & 3 \\
33 & 7 & Dra I & 3 \\
117 & 7 & Hind III & 3 \\
126 & 8 & Eco RV & 3 \\
13 & 9 & Eco RV & 2 \\
32 & 10 & Hind III & 2 \\
\hline
\end{tabular}


Table 3. PCR markers used in this study

\begin{tabular}{|c|c|c|c|c|}
\hline Marker & Type & Chromosome & $\begin{array}{l}\text { Restriction } \\
\text { Enzyme }\end{array}$ & $\begin{array}{l}\text { Number of } \\
\text { detected alleles }\end{array}$ \\
\hline S13048 & CAPS & 1 & Bam HI & 3 \\
\hline C955 & CAPS & 1 & $A f a \mathrm{I}$ & 2 \\
\hline S13994 & CAPS & 1 & $E c o$ RI & 2 \\
\hline C178 & CAPS & 1 & Hae III & 2 \\
\hline C137 & CAPS & 1 & Hind III & 2 \\
\hline C777 & STS & 2 & - & 2 \\
\hline S10844 & CAPS & 2 & Apa I & 3 \\
\hline C932 & CAPS & 2 & Hha I & 2 \\
\hline S1792 & CAPS & 3 & Hind III & 2 \\
\hline R2247 & CAPS & 3 & Hae III & 2 \\
\hline C1329 & CAPS & 3 & Eco T22I & 3 \\
\hline S1322 & CAPS & 4 & Hae III & 2 \\
\hline R00746 & STS & 4 & - & 3 \\
\hline R2232 & CAPS & 5 & Hha I & 5 \\
\hline R1436 & CAPS & 5 & Eco T14I & 3 \\
\hline C903 & STS & 5 & - & 2 \\
\hline S974 & CAPS & 5 & Mbo I & 2 \\
\hline S1520 & CAPS & 6 & Hind III & 2 \\
\hline R3879 & STS & 6 & - & 2 \\
\hline S11633 & CAPS & 7 & Xho I & 2 \\
\hline R1382 & CAPS & 7 & Xho I & 2 \\
\hline R1789 & CAPS & 7 & Mva I & 2 \\
\hline R1943 & CAPS & 8 & Hind III & 2 \\
\hline C166 & CAPS & 8 & Dra I & 2 \\
\hline R79 & CAPS & 9 & $\operatorname{Hinf} \mathrm{I}$ & 2 \\
\hline S1974 & CAPS & 9 & $\operatorname{Hinf} \mathrm{I}$ & 2 \\
\hline S1456 & CAPS & 9 & Mbo I & 2 \\
\hline C51124 & STS & 10 & - & 2 \\
\hline C63320 & STS & 10 & - & 2 \\
\hline C961 & CAPS & 10 & Dra I & 2 \\
\hline S11148 & CAPS & 10 & Eco T22I & 3 \\
\hline C562 & CAPS & 11 & Hind III & 2 \\
\hline C950 & CAPS & 11 & Eco RI & 2 \\
\hline S1436 & CAPS & 12 & Hind III & 2 \\
\hline
\end{tabular}

were electrophoresed on $2.0 \%$ agarose gels in $0.5 \times$ TBE buffer at $120 \mathrm{~V}$ for $2 \mathrm{~h}$, and stained with ethidium bromide.

\section{Data analysis}

The character was scored as 1 and 0 for the presence and absence of the fragment, respectively. The 1/0 matrix was used to calculate dissimilarity coefficients following Nei (1979). The resulting distance matrix was used to construct an unweighted pair-group method with arithmetic means (UPGMA, Sokal and Michener, 1958) dendrogram using software package PHYLIP (Felsenstein, 1993) to infer phylogenetic relationships. The stability of the nodes in the tree was tested by bootstrap analysis (Felsenstein, 1985). The data matrix was used to generate 1000 alternate data sets using SEQBOOT program. The alternate trees produced were used to construct a single majority-rule consensus tree using the CONSENSE program in PHYLIP package.

\section{RESULTS}

\section{DNA polymorphisms in Myanmar rice cultivars}

A total of 106 alleles were detected with an average of 2.4 alleles per locus using both 12 RFLP markers and
34 PCR markers. The total number of observed alleles per markers ranged from 2 to 5 . The CAPS marker R2232 showed the highest number of alleles, 5 (Table 3).

\section{Phylogenetic trees}

All accessions except CR351 and CR378 could be distinguished from each other by at least one DNA marker. The dendrogram revealed 2 well distinguished groups, named as Group I and Group II (Fig. 1). Group I seemed to correspond Japonica because it contained the accessions from Japan. It was further divided into subgroups Ia and Ib. Most accessions in the subgroup Ia were Japonica varieties originated in Japan, and all accessions contained in the subgroup Ib were Myanmar accessions. Although Myanmar accessions were divided from other Japonica varieties, the distance between the two subgroups was close and clearly differentiated from Group II.

Group II contained Indica accessions. It comprised subgroups (Ila, Ilb and IIc) plus accessions which formed no cluster (IId and IIe in Fig.1). The accessions of the subgroup Ile are found to be somehow distant from the subgroups IIa, Ilb, IIc and IId. Only one Myanmar accession (CR460) was included in the subgroup Ile.

Bootstrap analysis was performed to determine the confidence levels of the forks in the dendrogram. In the resulting consensus tree, only 6 forks had bootstrap values above $80 \%$ (Fig. 2). The grouping of the UPGMA tree and majority-rule consensus tree were in general comparable except the subgroups Ia, Ib, Ic and IId. The composition of Group I (subgroups Ia and Ib) and the subgroup Ile were identical in both dendrograms. However, most of the forks in the subgroups Ia, IIb, IIc and IId showed very low bootstrap values. The values of bootstrap analysis suggested that constituents of the subgroups IIa, IIb, IIc and IId were not significantly differentiated.

\section{Regional distribution}

Regional distribution of all groups classified in the UPGMA tree was shown in Fig. 3. The accessions classified in Group I were found only in central dry zone, coastal strip region and delta region. The accession CR460 belonging to the subgroup IIe was originated in coastal strip region.

\section{DISCUSSION}

A range of studies on the genetic diversity of natural populations of cultivated rice and wild rice species have been reported, including morphological, isozyme, and DNA levels (Oka, 1953a; Glazmann, 1987; Ishii et al., 1996; Fuentes et al., 1999; Joshi et al., 2000; Virk et al., 2000). However, studies on DNA level of Myanmar local rice varieties were very few. In the present study, 12 RFLP markers and 34 PCR markers were used to analyze 110 Myanmar landraces from core collection of Myanmar Seed Bank Project (Oka, 2000).

An average of 2.4 unique fragments per marker loci (Tables 2 and 3 ) is rather small compared with previous 


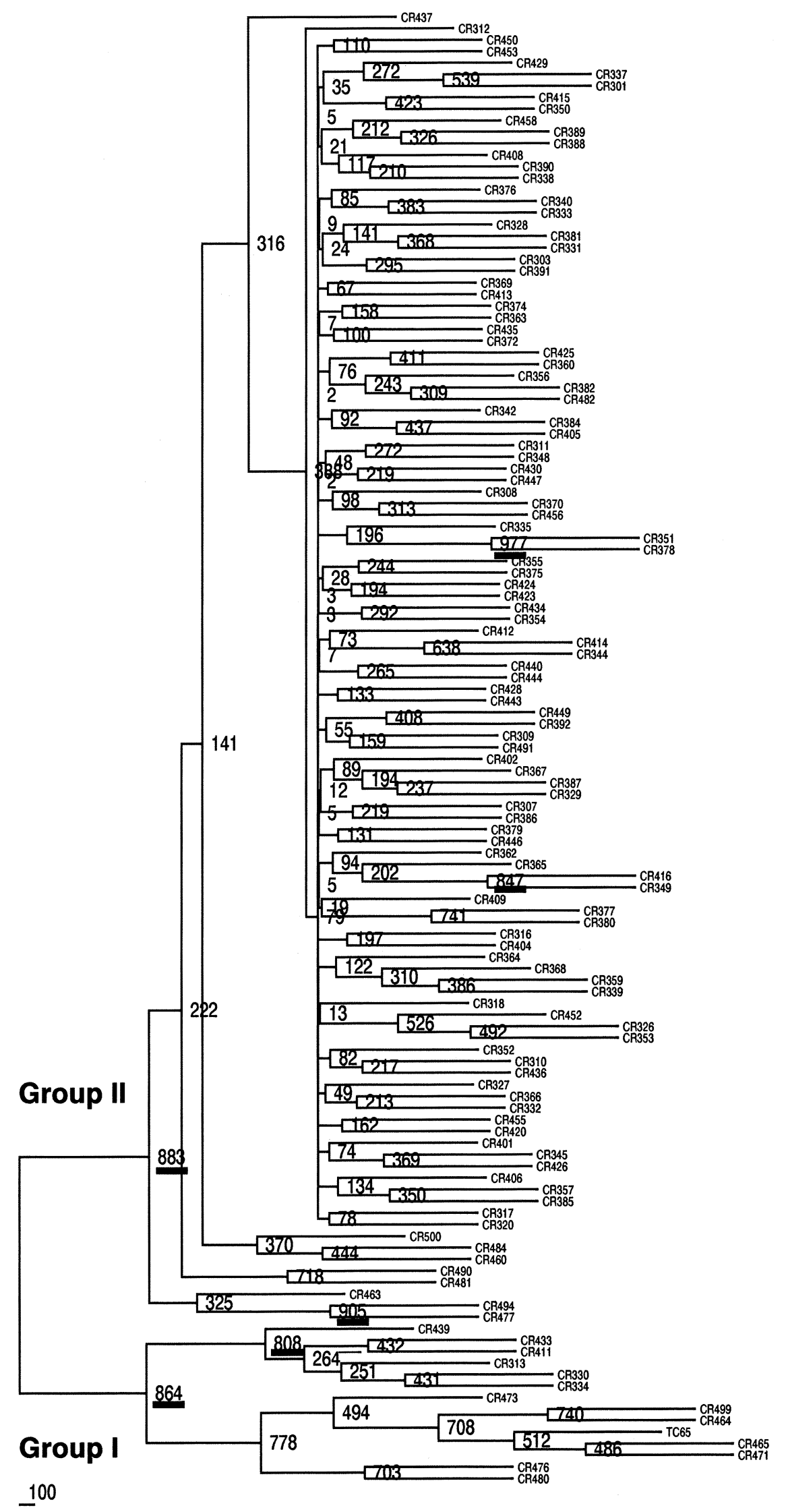

Fig. 2. A majority-rule consensus tree based on the analysis of most parsimonious tree from 1000 bootstrapped data sets generated by SEQBOOT program. The underlines indicate the bootstrap values greater than $80 \%$ (800) 
studies: average of 5.3 fragments observed in 192 accessions of A genome species (Doi et al., 2000). 3.4 fragments in 70 accessions of $O$. sativa (Wang and Tanksley, 1989) and 11.2 fragments in 93 accessions from whole genus Oryza (Wang et al., 1992). This is reasonable because the germplasm analyzed in this study are only cultivated rice and traditional varieties originated in Myanmar. Each pair of accessions showed a difference for at least one marker except CR351 and CR378, these accessions shared the identical genotype. This means that DNA marker is a powerful tool to classify germplasm.

Six accessions (CR313, CR330, CR334, CR433, CR439, and CR411) were classified into Group I (Fig. 1) which contained Japonica varieties from Japan. In the study of Kawase et al. (1991), genetic differentiation based on RFLP in Asian cultivated rice were well classified into two groups, Indica and Japonica, and Myanmar rice cultivars were included in both groups. Our results indicated that Japonica-like Myanmar accessions (subgroup Ib) were clearly differentiated from Japanese varieties (subgroup Ia), suggesting that these Myanmar accessions might be Javanica or tropical Japonica accessions. Adding more control accessions belonging to tropical Japonica should be helpful to clarify this question. Climate conditions, geographical heterogeneity or the wide area of rice cultivation in central dry zone, coastal strip region and delta region might be the reason for that these Japonica-like accessions were found (Fig. 3).

The majority rule consensus tree generated from bootstrap analysis (Fig. 2) indicated that only six nodes showed the stability greater than $80 \%$. The significance of these nodes enforced the pattern of clustering of the subgroups Ia, Ib and IIe (Figs. 1 and 2). However, most of the forks in the subgroups Ia, IIb, IIc and IId showed low bootstrap values and unstable (Fig. 2). This indicated that constituents of these subgroups were not significantly differentiated. A similar pattern of the difference between the methods of the dendrogram construction was reported in Triticeae tribe (Monte et al., 1993).

Previous studies also suggested that Myanmar rice varieties are high in genetic variation. In analysis of esterase isozyme, the highest genetic diversity was found in the area covering Myanmar, Thailand, Laos, and Yunnan Province of China (Nakagahra et al., 1984). The results presented in this study indicated that Myanmar rice genetic resources are diverse in molecular level. The knowledge on genetic variation is important for breeders to fully draw the potential of germplasm. It is required to know the genetic diversity as the basic information. This is the first study on the genetic variation of Myanmar rice in DNA levels and the information generated from this experiment would allow us to select appropriate parents within Myanmar rice cultivars for further breeding program.

\section{REFERENCES}

Chang, T. T. 1976 The origin, evolution, cultivation, dissemination, and diversification of Asian and African rice.

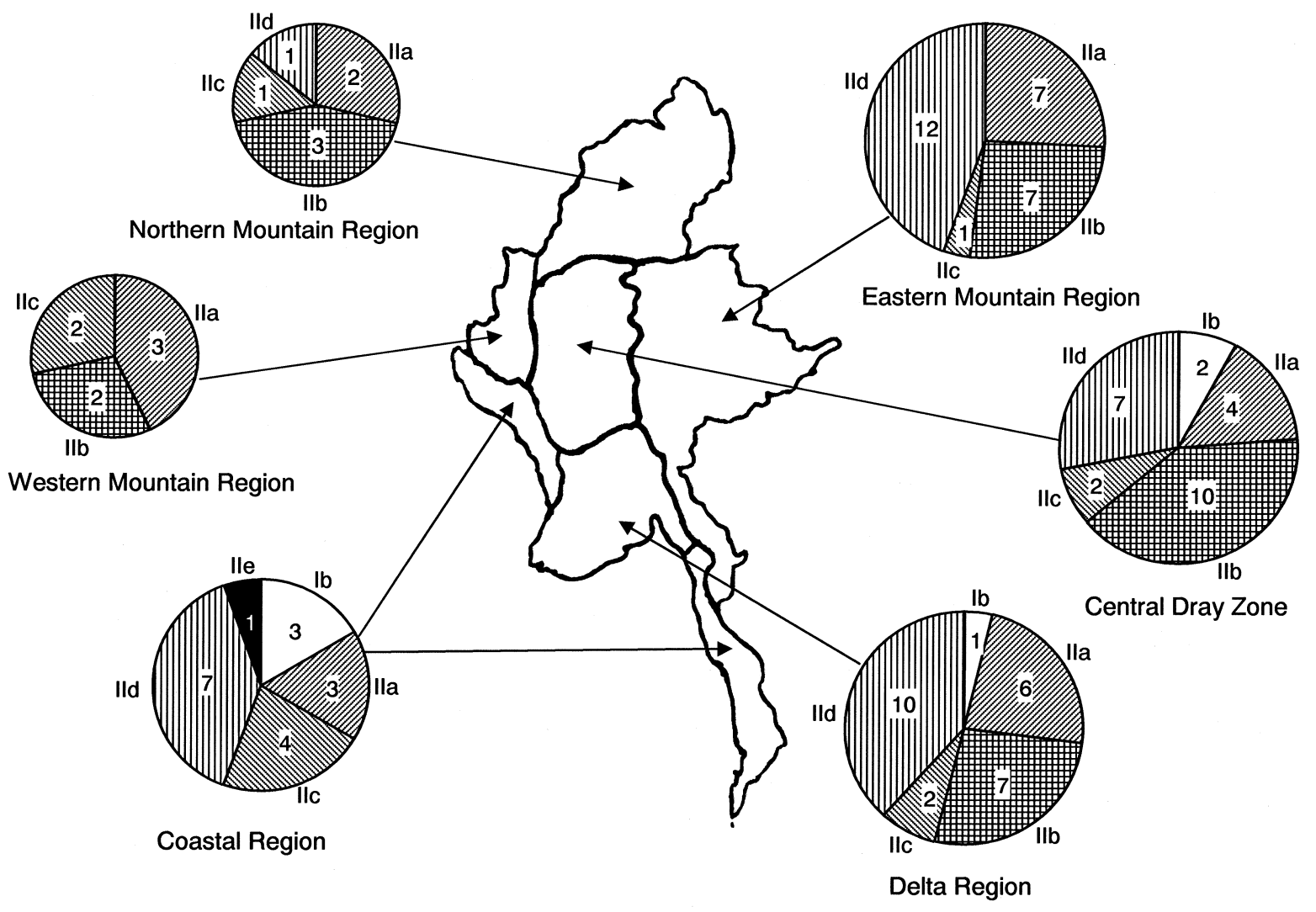

Fig. 3. Geographical distribution of the DNA marker-based groups of Myanmar accessions. 
Euphytica, 25: 425-441

Chen, H. B., J. M. Martin, M. Lavin, and L. E. Talbert 1994 Genetic diversity in hard red spring wheat based of Sequence-Tagged-Site PCR markers. Crop Sci., 34: 1628-1632

Doi, K., M. Nakano Nonomura, A. Yoshimura, N. Iwata and D. A. Vaughan 2000 RFLP relationships of A-genome species in the genus Oryza. J. Fac. Agr., Kyushu Univ., 45: 83-98

Enoki, H., H. Sato and K. Koinuma 2002 SSR analysis of genetic diversity among maize inbred lines adapted to cold regions of Japan. Theor. Appl. Genet, 104: 1270-1277

Flesenstein, J. 1985 Confidence limits on phylogenies: an approach using the bootstrap. Evolution, 39: 783-791

Flesenstein, J. 1993 PHYLIP The Phylogeny Inference Package. http://evolution.gs.washington.edu/phylip.html

Fuentes, J. L., F. Escobar, A. Alvarez, G. Gallego, M. C. Duque, M. Ferrer, J. E. Deus and J. M. Tohme 1999 Analysis of genetic diversity in Cuban rice varieties using isozyme, RAPD and AFLP markers. Euphytica, 109: 107-115

Ghebru, B., R. J. Schmidt and J. L.Bennetzan 2002 Genetic diversity of Eritrean sorghum landraces accessed with simple sequence repeat (SSR) markers. Theor. Appl. Genet., 105: 229-236

Ghreyazie, B., N. Haung, G. Second, J. Bennett and G. S. Khush 1995 Classification of rice germplasm. I. Analysis using ALP and PCR based RFLP. Theor. Appl. Genet, , 91: 218-227

Glaszmann, J. C. 1987. Isozyme classification of Asian rice varieties. Theor. Appl. Genet., 74: 21-30

Ishii, T., T. Nakano, H. Maeda and O. Kamijima 1996 Phylogenetic relationships in A-genome species of rice as revealed by RAPD analysis. Genes Genet. Syst., 71: 195-201

Jackson, M. T., J. L. Pham, H. J. Newbury, B. V. Ford-Lloyd and P. S. Virk 1998 A core collection of rice-needs, opportunities, and constraints-. In "Core collections for today and tomorrow" ed. by R. C. Johnson and T. Hodgkin, International Plant Genetic Resources Institute, Rome (Italy)

Joshi, S. P., V. S. Gupta, R. K. Aggarwal, P. K. Ranjekar and D. S. Brar 2000 Genetic diversity and phylogenetic relationship as revealed by inter simple sequence repeat (ISSR) polymorphism in the genus Oryza. Theor. Appl. Genet., 100: $1311-1320$

Kawase, M., N. Kishimoto, T. Tanaka, A. Yoshimura, S. Yoshimura, K. Saito, A. Saito, M. Yano, N. Takeda, T. Nagamine and M. Nakagahra 1991 Intraspecific variation and genetic differentiation based on restriction fragment length polymorphism in Asian cultivated rice, Oryza sativa L. In "Rice Genetics II", International Rice Research Institute, Manila (Philippines), pp. 467-473

Konieczny, A. and F. F. Ausubel 1993 A procedure for mapping Arabidopsis mutations using co-dominant ecotype-specific PCR-based markers. Plant J., 4: 403-410

Matsuo, T. 1997 Origin and distribution of cultivated rice. In "Science of the Rice Plant" Vol. 3 Genetics, ed. by T. Matsuo et al., Food and Agriculture Policy Research Center, Tokyo (Japan), pp. 69-88

Montae, J. V., C. L. McIntyre and J. P. Gustafson 1993 Analysis of phylogenetic relationships in the Triticeae tribe using RFLPs. Theo. Appl. Genet., 86: 649-655

Murry, M. G. and W. F. Thompson 1980 Rapid isolation of high molecular weight plant DNA. Nucl. Acids. Res., 8: 4321-4325

Nakagahra, M. 1978 The differentiation, classification and genetic diversity of cultivated rice (Oryza sativa L.) by isozyme analysis. Trop. Agric. Res. Sci., 11: 77-82

Nakagahra, M. 1984 Geographical distribution of esterase genotypes of rice in Asia. Rice Genet. Newsletter; 1: 118-120

Nakano, M., A. Yoshimura and N. Iwata 1992 Phylogenetic study of cultivated rice and its wild relatives by RFLP. Rice Genet. Newsletter, 9: 132-134
Nei, M. 1987 Molecular Evolutionary Genetics. Columbia University Press, New York (USA)

Oka, H. I. 1953a Phylogenetic differentiation of the cultivated rice plant. I. Variation of various characters and character combinations among rice varieties. Jpn. J. Breed., 3: 33-43 (in Japanese with English summary)

Oka, H. I. 1953b Phylogenetic differentiation of the cultivated rice plant. II. Classification of rice varieties by intervarietal hybrid sterility. Jpn. J. Breed., 3: 1-6 (in Japanese with English summery)

Oka, M. 2000 Current situation of PGR management in Myanmar. (a seminar abstract)

Perry, D. J., N. Isabel and J. Bousquet 1999 Sequencetagged-site (STS) markers of arbitrary genes: the amount and nature of variation revealed in Norway spruce. Heredity, $\mathbf{8 3}$ : 239-248

Saito, A., M. Yano, N. Kishimoto, M. Nakagahra, A. Yoshimura, K. Saito, S. Kuhara, Y. Ukai, M. Kawase, T. Nagamine, S. Yoshimura, O. Ideta, R. Ohsawa, Y. Hayano, N. Iwata and M. Sugiura 1991 Linkage map of restriction fragment length polymorphism loci in rice. Jpn. J. Breed., 41: 665-670

Shim, S. I. and R. B. Jørgensen 2000 Genetic structure in cultivated and wild carrots (Daucus carota L.) revealed by AFLP analysis. Theor. Appl. Genet., 101: 227-233

Skroch, P. W. and J. Nienhuis 1995 Qualitative and quantitative characterization of RAPD variation among snap bean (Phaseolus vulgaris) genotypes. Theor. Appl. Genet., 91: 1078-1085

Sokal, R. R. and C. D. Michener 1958 A statistical method for evaluating systematic relationships. Sci. Bull. Univ. Kansas, 38: 1409-1438

Sun, C. Q., X. K. Wang, Z. C. Li, A. Yoshimura and N. Iwata 2001 Comparison of the genetic diversity of common wild rice (Oryza rufipogon Griff.) and cultivated rice (O. sativa L.) using RFLP markers. Theor. Appl. Genet., 102: 157-162

Tsumura, Y., Y. Suyama, K. Yoshimura, N. Shirato and Y. Mukai 1997 Sequence-tagged-sites (STSs) of cDNA clones in Cryptomeria japonica and their evaluation as molecular markers in conifers. Theor. Appl. Genet, 94: 764-772

Vavilov, N. 1926 Studies on the origin of cultivated plants. Bull. Appl. Bot. Plant Breed., 16: 139-248

Virk, P. S., B. V. Ford-Lloyd, M. T. Jackson, H. S. Pooni, T. P. Clemeno and H. J. Newbury 1996 Predicting quantitative variation within rice germplasm using molecular markers. Heredity, 76: 296-304

Virk, P. S., J. Zhu, H. J. Newbury, G. J. Bryan, M. T. Jackson and B. V. Ford-Lloyd 2000 Effectiveness of different classes of molecular marker for classifying and revealing variation in rice (Oryza sativa) germplasm. Euphytica, 112: 275-284

Vos, P., R. Hogers, M. Bleeker, M. Reijans, T. van de Lee, M. Hornes, A. Frijters, J. Pot, J. Peleman and M. Kuiper 1995 AFLP: a new technique for DNA fingerprinting. Nucl. Acids Res., 23: 4407-4414

Wang, Z. Y. and S. D. Tanksley 1989 Restriction fragment length polymorphism in Oryza sativa L. Genome, 32: 1113-1118

Wang, Z. Y., G. Second and S. D. Tanksley 1992 Polymorphism and phylogenetic relationships among species in the genus Oryza as determined by analysis of nuclear RFLPs. Theor. Appl. Genet., 83: 565-581

Williams J. G., A. R. Kubelik, K. J. Livak, J. A. Rafalski and S. V. Tingey 1990 DNA polymorphism amplified by arbitrary primers are useful as genetic markers. Nucl. Acids Res., 18 6531-6535.

Zhang, Q., M. A. Saghai Maroof, T. Y. Lu and B. Z. Shen 1992 Genetic diversity and differentiation of indica and japonica rice detected by RFLP analysis. Theor. Appl. Genet., 83: 495-499 